https://doi.org/10.48009/1_iis_2007_160-166

\title{
EFFECTIVENESS OF ONLINE LEARNING PROGRAM: A CASE STUDY OF A HIGHER EDUCATION INSTITUTION
}

\author{
Omamerhi Ebojoh, Central Michigan University, Osevw1oe@cmich.edu \\ Hongjiang Xu, Central Michigan University, xu1h@cmich.edu
}

\begin{abstract}
Online learning has become a popular tool in addition to traditional learning methods. This study emphasizes on how assessment and delivery methods employed can influence the effectiveness of online program, as well as the benefits and constrains experienced in e-learning. The research project was conducted at a Higher Educational Institution for a period of three months. A case study methodology was employed to investigate the opinions and experiences of faculty and students involved in online programs. Various factors that affect the effectiveness of online programs were studied in order to provide insights on the major challenges, benefits and limitations faced. Among the findings, major problem areas were identified and suggestions were proposed on how identified problems can be minimized. The study also raised future direction for e-learning.
\end{abstract}

Keywords: Online Learning, Electronic Learning, Higher Education

\section{INTRODUCTION}

Learning has evolved from the traditional classroom to distance learning and now to online learning, where students learn in "invisible classrooms" (Phillip, 1998; Sutherland, 1999). With the advancement of technology and the Internet, educational institutions are changing their learning techniques to meet demands of user in providing an ideal learning environment. The use of e-learning methods involves the possibility of learning from information delivered electronically through sending, receiving emails, online courses, online discussion forums, video conferencing, CD Rom, etc. (Cappel, Hayen 2004).

Universities and higher education have partnered with information training vendors to create a virtual learning environment in which a wide range of levels and disciplines of academic degrees and certificate programs are managed through a consistent user interface standard throughout the institution. Online only colleges and campus colleges offer some programs requiring students to attend some campus classes with orientations sessions. (Nunamaker et al, 2004).

Online learning method is more cost effective than traditional classroom learning but there are many issues arising within the context of self study independent study programs from the end users perspective. There is a need to observe and analyze these situations in order to discover areas of improvement in the design delivery methods employed.

\section{Purpose of Study}

The purpose of this study is to theoretically and empirically assess how online learning programs can me managed more effectively in Higher education institutions.

\section{Research Problem}

This study examines how Online Learning Programs can be made more effective.

\section{Sub Problems}

The sub problems are as follows;

- What assessments are put in place to evaluate online learning programs?

- What major constraints limit the usefulness of online learning?

- What major benefits are obtained in online program?

- What are the major delivery methods?

\section{LITERATURE REVIEW}

E-learning is defined "as the process of learning online, especially through the Internet and email". (Webster's New Millennium ${ }^{\mathrm{TM}}$ Dictionary of English). Online learning is defined as "an e-learning method where a student can learn at any time or location over the internet. (Shabha 2004 ). E learning involves more than information transfer between an instructor and participants where selected readings and lectures are sent to the participants who then respond with assignments and examinations. (Benbunan-Fich 2003). Virtual Learning Environment is defined as "a software system 
designed to facilitate teachers in the management of educational courses for their students" (www.wikipedia.org).There are two major types of elearning which are Asynchronous and synchronous elearning. Asynchronous e-learning allows the student to participate based on time and schedule, without live interaction with the instructor While Synchronous e-learning involves interacting with an instructor via the Web in real time. (Mehlenbacher B et al 2000)

E-learning method is cost effective, learner centered, time and location flexibility which makes it feasible for global audience (Nunamaker et al, 2004). Online learning method involves registration, assessments, testing, certification development, payments activities. (Munro R, 2005). Some of the benefit of online learning includes the flexibility for students to schedule their studies at their convenience and faculty can reuse prepared course materials. (Neumann 1998).According to Nunamaker et al, (2004), e-learning method increases the preparation time for instructor and lacks the need for immediate feedback in asynchronous method. Learners are often uncomfortable with the design delivery method which often make them puzzled and frustrated. Since information is delivered electronically, learners need to identify what section of the material is considered relevant. A survey conducted by the Campaign for learning found that $58 \%$ of people attempt to learn at their desks in the office while $29 \%$ of the people preferred to learn at home. (Honey P 2001).The effectiveness of the online programs can be improved by increasing the interaction between students and online program developer to examine issues arising in the design delivery methods. (Neumann 1998). There is need to study the learners characteristics, program requirement and reorganize the design procedure to obtain an increased effect on learners overall performance. (Munro 2005).

Summary of Literature Review.

Table 1. The review of the existing literature on online learning.

\begin{tabular}{|c|c|c|c|c|}
\hline ARTICLE ID & $\begin{array}{l}\text { TOPIC } \\
\text { AREA }\end{array}$ & $\begin{array}{l}\text { RESEARCH } \\
\text { APPROACH }\end{array}$ & $\begin{array}{l}\text { DATA } \\
\text { ANALYSIS }\end{array}$ & $\begin{array}{l}\text { MAJOR } \\
\text { FINDINGS }\end{array}$ \\
\hline $\begin{array}{l}\text { (Neumann } \\
\text { 1998) }\end{array}$ & $\begin{array}{l}\text { Distance } \\
\text { Learning }\end{array}$ & Qualitative & $\begin{array}{l}\text { Develop pro and } \\
\text { cons of e-learning }\end{array}$ & $\begin{array}{l}\text { Highlights the various benefits of e- } \\
\text { learning }\end{array}$ \\
\hline $\begin{array}{l}\text { (Mehlenbacher } \\
\text { B et al 2000) }\end{array}$ & $\begin{array}{l}\text { Distance } \\
\text { Learning }\end{array}$ & Quantitative & $\begin{array}{l}\text { Mean, standard } \\
\text { deviation, } \\
\text { correlation. }\end{array}$ & $\begin{array}{l}\text { The study highlights the complexity } \\
\text { of effective teaching. }\end{array}$ \\
\hline (Honey P 2001). & E-learning & Qualitative & $\begin{array}{l}\text { Develop pro and } \\
\text { cons of e-learning }\end{array}$ & $\begin{array}{l}\text { Provided areas of improvement and } \\
\text { performance appraisal. }\end{array}$ \\
\hline $\begin{array}{l}\text { (Benbunan-Fich } \\
\text { 2003) }\end{array}$ & $\begin{array}{l}\text { Online } \\
\text { courses }\end{array}$ & Quantitative & $\begin{array}{l}\text { Null Hypothesis, } \\
\text { Correlation. }\end{array}$ & $\begin{array}{l}\text { The outcomes of online courses } \\
\text { improved when professors structured } \\
\text { them to support the growth of the } \\
\text { learning community. }\end{array}$ \\
\hline $\begin{array}{l}\text { (Nunamaker et } \\
\text { al 2004). }\end{array}$ & $\begin{array}{l}\text { E-learning, } \\
\text { classroom } \\
\text { learning. }\end{array}$ & Quantitative & $\begin{array}{lr}\text { Liker } & \text { scale, } \\
\text { comparison } & \text { of } \\
\text { average scores } & \text { in } \\
\text { two studies. } & \\
\end{array}$ & $\begin{array}{l}\text { Comparison of e-learning with } \\
\text { classroom learning. }\end{array}$ \\
\hline $\begin{array}{l}\text { (Kim E. et al } \\
\text { 2004) }\end{array}$ & $\begin{array}{l}\text { Web based } \\
\text { distance } \\
\text { courses }\end{array}$ & Quantitative & $\begin{array}{l}\text { Arithmetic mean, } \\
\text { correlation } \\
\text { coefficient }\end{array}$ & $\begin{array}{l}\text { Student personality affect the grade } \\
\text { achievement in web based program }\end{array}$ \\
\hline $\begin{array}{ll}\text { (Munro } R \text {, } \\
\text { 2005) }\end{array}$ & E-learning & Qualitative & $\begin{array}{l}\text { Study the different } \\
\text { style of e-learning. }\end{array}$ & $\begin{array}{l}\text { Common tool and technique involved } \\
\text { in online learning. }\end{array}$ \\
\hline $\begin{array}{l}\text { (Tham } M \text { et al } \\
\text { (2005). }\end{array}$ & E-Learning & Qualitative & $\begin{array}{ll}\text { Assessing } & \text { online } \\
\text { learning } & \\
\text { effectiveness } & \\
\end{array}$ & $\begin{array}{l}\text { Common issues and constraints } \\
\text { involved in online learning. }\end{array}$ \\
\hline $\begin{array}{l}\text { (Mackay S et al } \\
\text { (2006). }\end{array}$ & $\begin{array}{l}\text { Classroom, } \\
\text { E-Learning }\end{array}$ & Qualitative & $\begin{array}{l}\text { Compared various } \\
\text { learning methods }\end{array}$ & $\begin{array}{lll}\text { Blended approach } & \text { results } & \text { to } \\
\text { substantial benefits. } & & \end{array}$ \\
\hline
\end{tabular}




\section{Theoretical Framework}

After a thorough review of the literature an initial theoretical framework is drawn in relation to the measures relevant to the evaluation of effectiveness of online programs. This research work is based on the impact of the major benefits, constraints, assessments and delivery methods on evaluating the effectiveness of online programs.

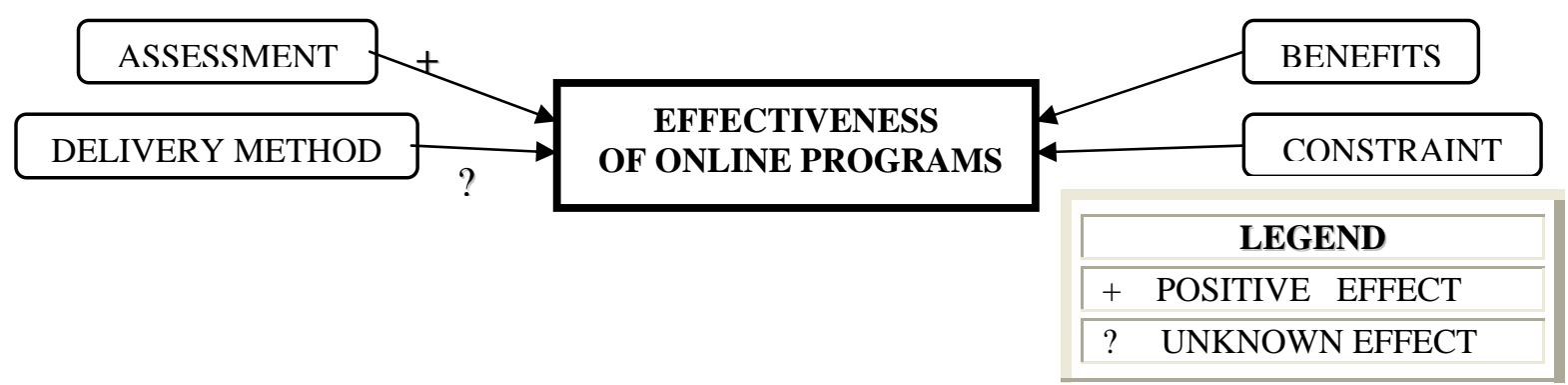

Figure 1: The proposed model for effectiveness of online programs.

Constraints observed offers a positive effect while the delivery method effect is unknown since it is dependent on the type of delivery method employed in the program. Assessment tools are evaluations set in place to ensure users are acquiring the necessary skills for a particular program. (Munro R ,2005). The assessment tools employed offers a positive effect on the effectiveness of online program. Delivery Method is the systematic way of identifying what the audience needs and it involves the development of a learning process tailored to suits the needs. (Douglas $\mathrm{D}$ et al 2004).The benefits identified in online program offers a positive effect on the evaluation of the effectiveness of online program. (Neuman 1998). Constraints are identified as the limitations and difficulties faced by users involved in online program. (Honey P 2001). The model shows an environment with a problem but still institutions continue to offer online programs without trying to rectify difficulties users encounter. The delivery method effect needs to be identified to ascertain the effectiveness of online programs.

\section{METHODOLOGY}

\section{Research Method}

The approach to the study is qualitative and is employed to give full description of several situations and relationships, interpret several cases in order to gain new knowledge, develop concepts and identify other areas of concern. The qualitative approach was also employed for the purpose of verification of several assumptions, theories and the evaluation of particular principles practice or innovations. (Leedy et al, 2005).The design of the study makes use of a combination of Case study with Phenomenological study. The case study design was chosen because it involves an in-depth study of a program or event within a specified time while phenomenological approach was used to understand the several experiences from the participants view point. (Leedy et al, 2005). Both Qualitative designs were employed for the purpose of understanding in great depth several situations and experiences of respondents in order to solve the identified research problem.

\section{Justification of the research}

The participating respondents are obtained from the various departments and colleges in the University. The respondents signed a non-disclosed consent document and were fully aware of the purpose and usage of the research paper. The combination of interviews and appropriate written documents was used to study participant's responses to the evaluation of the effectiveness of online programs.

\section{Data Collection Strategies}

The case study site selected in this study is a Higher Education Institute in a Sub-urban Town located in USA. It is a multifaceted national university that offers students more than 170 programs at the Bachelor's, Master's, Specialist's, and Doctoral levels. The University has extensive experience in online and distance learning programs to support students offering online classes for various courses in different colleges.

The nature of the data is qualitative using internal and external documents. The data collection method involved the use of official record and interview sessions which provides flexibility to the study with the option of face to face, phone and email interview. 
The university surveyed consists of eight colleges with each college representing a cluster. Random selection was carried out to select three clusters from the eight clusters. The colleges selected are: College of Health Profession (CHP), College of Humanities, Social and Behavioral Studies (CHSBS) and College of Graduate Studies (CGS). The participant of the study consists of a faculty staff and two students from each selected cluster making a total of nine participant. The participants were randomly selected to ensure bias was prevented.

\section{Methods of Achieving Validity and Reliability}

Thick description: an in depth description on how online programs can be managed effectively is explained for readers to draw conclusions from the data. The content of the research paper should not be vague, it should be self explanatory.

Content validity: the data collected was obtained from individual who had experiences in the area been studied. It involves assessing people's achievement in several areas e.g. studying students with experiences in online program.

Feedback from others: The research is examined by my instructor in order to examine proper analysis and interpretation of data.
Participant validation: Conclusions drawn at the end will be discussed with participant to find out if participants agree with the conclusions drawn, and also if the conclusions drawn are relevant based on their experience.

Interrater reliability: the participants from different colleges yielded similar responses on the evaluation of the effectiveness of online programs.

\section{Data Analysis}

The goal of the study is to investigate several situations that affect the effectiveness of online programs. Certain facts concerning the sub problems are categorized and arranged in a chronological order.

$>$ Detailed description of the data collected is analyzed and categorized into several common and meaningful themes.

According to the data in table 2 all the colleges examined had similar characteristics offered by each college which includes certificate and masters program online, similar communication and assessment tools. The major differences can be observed in the communication tools and delivery methods employed by the colleges. The colleges make use of either or both synchronous and asynchronous delivery method.

Table 2. Categorization of data according to common themes of descriptive information for colleges

\begin{tabular}{|l|l|l|l|}
\hline Common Themes & $\begin{array}{l}\text { College Of Humanities, } \\
\text { Social \& Behavioral Studies }\end{array}$ & $\begin{array}{l}\text { College Of Graduate } \\
\text { Studies }\end{array}$ & $\begin{array}{l}\text { College Of Health } \\
\text { Professions }\end{array}$ \\
\hline Users & Students and Faculty Staff & Students and Faculty Staff & Students and Faculty Staff \\
\hline Users Code name & CHSBS1, CHSBS2, CHSBSF & CGS1, CGS2, CGSF & CHP1, CHP2, CHPF \\
\hline Program Types & Certificate and Masters & Certificate and Masters & Certificate and Doctorate \\
\hline Duration & 2yrs- 5yrs & 2yrs - 5yrs & 3yrs - 5yrs connection, \\
\hline Basic requirement & $\begin{array}{l}\text { Internet \& connection, } \\
\text { Telephone, Audio features }\end{array}$ & $\begin{array}{l}\text { Internet } \\
\text { Telephone, Audio features }\end{array}$ & $\begin{array}{l}\text { Internet } \\
\text { Telephone, Audio features }\end{array}$ \\
\hline Delivery method & Asynchronous design & Synchronous design & $\begin{array}{l}\text { Synchronous } \\
\text { Asynchronous design }\end{array}$ \\
\hline $\begin{array}{l}\text { Communication } \\
\text { Tools }\end{array}$ & $\begin{array}{l}\text { Remote access software, } \\
\text { Email, Blackboard, } \\
\text { Discussion board }\end{array}$ & $\begin{array}{l}\text { Online library, Blackboard, } \\
\text { Email. }\end{array}$ & $\begin{array}{l}\text { Online library, Email, } \\
\text { Blackboard, Discussion } \\
\text { board. }\end{array}$ \\
\hline
\end{tabular}

The data is examined and interpreted by identify patterns and common themes which is then synthesis into an overall portrait of the study

Answers to research sub problems
$>$ Identification of patterns related to several sub problems are observed in the data collected and interpreted.

According to the data in table 3 all the colleges examined had different communication and delivery problems. 
Table 3. Detailed research findings of research sub problems.

\begin{tabular}{|l|l|l|l|}
\hline & $\begin{array}{l}\text { College Of Graduate } \\
\text { Studies }\end{array}$ & $\begin{array}{l}\text { College Of Humanities, } \\
\text { Social \& Behavioral Studies }\end{array}$ & $\begin{array}{l}\text { College Of Health } \\
\text { Professions }\end{array}$ \\
\hline $\begin{array}{l}\text { Assessment } \\
\text { Tools }\end{array}$ & $\begin{array}{l}\text { Exams, quiz, group, } \\
\text { projects, assignments, } \\
\text { research papers. }\end{array}$ & $\begin{array}{l}\text { Exams, assignments, research } \\
\text { papers. }\end{array}$ & $\begin{array}{l}\text { Exams, quiz, assignments } \\
\text { projects, papers, seminars, } \\
\text { dissertation, field trips. }\end{array}$ \\
\hline $\begin{array}{l}\text { Delivery Method } \\
\text { Issues }\end{array}$ & Delayed Feedback & $\begin{array}{l}\text { Time management for } \\
\text { discussion group }\end{array}$ & $\begin{array}{l}\text { Time Consuming, High } \\
\text { Writing Intensity }\end{array}$ \\
\hline $\begin{array}{l}\text { Major } \\
\text { Constraints }\end{array}$ & $\begin{array}{l}\text { hardware \& software } \\
\text { failure }\end{array}$ & $\begin{array}{l}\text { Web issues, loss of critical } \\
\text { data, hardware \& software } \\
\text { failure, blackboard problem }\end{array}$ & $\begin{array}{l}\text { Loss of critical data. Flexibility } \\
\text { to print contents of screen }\end{array}$ \\
\hline Major Benefits & $\begin{array}{l}\text { Good and reusable } \\
\text { course materials, blend } \\
\text { of learning methods }\end{array}$ & $\begin{array}{l}\text { Time and location flexibility, } \\
\text { cost effective, interactive } \\
\text { discussion, self paced learning. } \\
\text { Fast Feedback }\end{array}$ & $\begin{array}{l}\text { Location and time flexibility, } \\
\text { Student Centered learning, } \\
\text { Enriched Course Materials }\end{array}$ \\
\hline
\end{tabular}

The various programs had similar benefits and assessment tools but the major issue observed was in communication and delivery methods employed. Students surveyed were satisfied with the assessment tools used in the programs. The assessment tools enabled students acquire the necessary skills offered by the program. The delivery method issues differ in relation to the colleges since it is dependent on the course description of the program. A good delivery method involves the layout, presentation and release of the course materials between student and instructor. Students receive study guide and book supplementary readings and send assignments via email to instructor. (CGS, 2006). Examples of poor delivery method involve mailing of assignments to instructor which could take days to weeks.

\section{Units of Analysis- By Colleges}

College of Humanities and Social and Behavioral Studies - Asynchronous learning method was employed in this college which involves students communicating with team members or professors at a particular time. The use of discussion forum was very effective and useful for interactive discussions during teamwork. (CHSBS2, 2006). The assessment tools used are exams, group projects, individual projects, quizzes, research papers and assignment. Extensive use of email and web based discussion forum was the major communication ties between professors and students. (CHSBS1, 2006). The communication issue faced by students was due to delayed response between participants and connectivity problems experienced. A major aspect of the program involves interacting with people and development of communication skills this can't be built effectively by online learning.

College of Graduate Studies - Synchronous learning method was employed in this college which enables students to communicate with professor at any time. The program involves student centered learning which provides flexibility in terms of time management. (CGSF, 2006).The communication issues faced by students consist of hardware and software problems experience by users. The assessment tools used are exams, individual projects, quizzes, research papers and assignment.

College of Health Professions - The program makes use of enriched course materials however it involves high writing intensity which is time demanding. (CHP1, 2006). Both asynchronous and synchronous learning method is employed in this college. The program delivery method involves field trip and seminar where students interact and share ideas. These few trips present a classroom feeling which creates a sense of motivation especially the knowledge of other students sharing similar experiences. (CHP2, 2006).The assessment tools used are exams, research papers, individual projects, quizzes, assignment and dissertation. The communication issues faced by students and faculty are internal and external problems.

\section{FINDINGS}

Based on the analyzed data and literature review it is obvious that there is still a gap in design delivery methods employed in online programs which needs to be examined. Comparison across data sources, time and methods used to interpret the data. The findings from the interview reveals that majority of the respondent are satisfied with the assessment tools in place and encounter similar communication and design delivery issues. Communication issue was a major source of frustration faced by users. Designers of online programs need to tackle the various communication problems. The use of discussion 
board, charts and interactive technology enhances communication between users and faculty.

The various colleges require both good assessment tools and appropriate delivery methods as the essential ingredients to enable the effectiveness of online program. The constraints can be minimized with effective design delivery. As result of the study, the following figure 2 shows the final framework based on study findings:

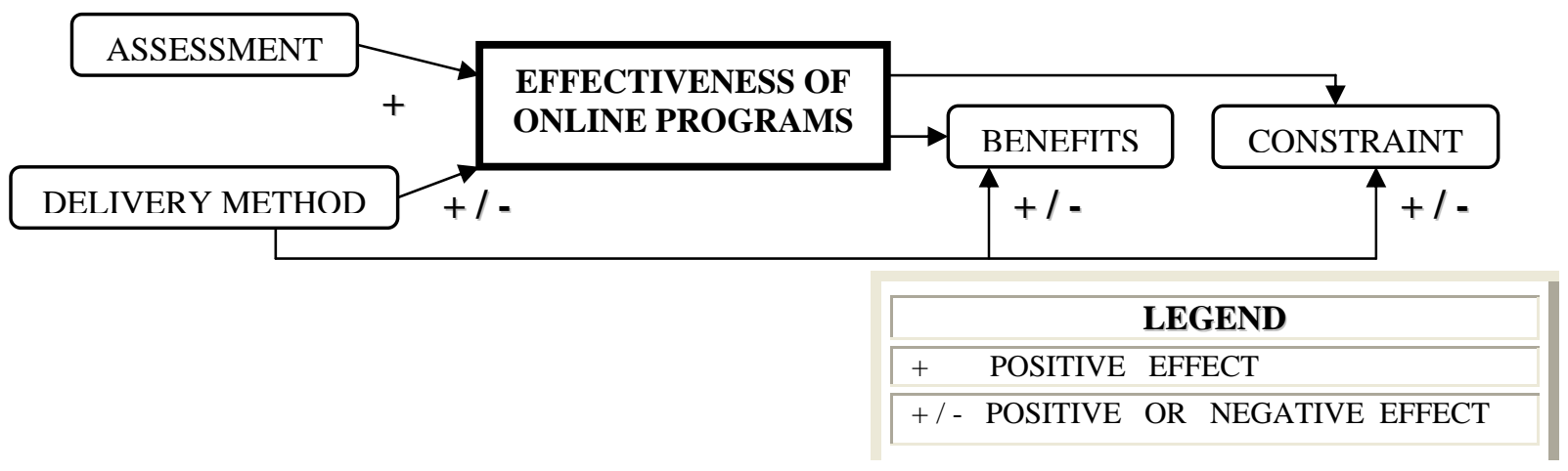

Figure 2: The model for effectiveness of online programs.

The delivery method can have either a positive or negative effect on the benefits and constraint of the effectiveness of online program. The delivery method needs to be identified, examined and applied successfully in order for online program to be effective. If the design delivery is not satisfactory it affects the benefits and constraints observed by students. For example if the students partake in an online program that had ineffective delivery method. The students would draw more constraints than benefits on the effectiveness of online program. The delivery method on the other hand is related negatively to the constraints, but can help minimize the level of constraints involved in online program.

\section{Discussion and recommendations}

Based on the findings of the study there is a mixture of factors that influence the effectiveness of online learning programs which includes the assessment, benefits, constraints and the design delivery method. The assessment, benefits and constraints are dependent on the design delivery which has an effect on the evaluation of the effectiveness on online program. Each of theses variable have either a positive or a negative effect on the design delivery and the effectiveness of online learning, while the design delivery plays a major role in the evaluation of the effectiveness of online programs. Communication issues can be minimized by users having access to help desk or units which would provide immediate assistance. More thorough design should be employed during the development stage of online course and program design.

\section{CONCLUSION AND FUTURE DIRECTIONS}

The case study findings offer support for the proposition that measurable improvements can be made in the design delivery of online program. The research shows that design delivery can be improved by upgrading or enhancing the technology used in communication e.g. video conferencing, electronic portfolio, discussion forum and also by developing an effective plan for the quality of course materials, course workload and schedule of the program. In addition to the suggestions put forth in the discussion above, there is need for more research on the role of self disciple on the effectiveness on online program. Another area for future research studies involves studying various samples, technologies and course contents to highlight more areas of difficulties encountered. Additional research would enable academicians to make better decision on how elearning can be used more effectively under several circumstances and on a large scaled survey.

\section{REFERENCES}

1. Benbunan-Fich R, Hiltz S. (2003). Mediators of the Effectiveness of Online Courses. IEEE Transactions on Professional Communication. 46(4), 298

2. Bonham W, Beichner R, Titus A , Martin L .(2000). Educational Research Using Web based Assessment Systems, Journal of Research on Computing in Education. 33.1 
3. Cappel J, Hayen R. ( 2004) . Evaluating ELearning: A Case Study. The Journal of Computer Information Systems. 44(4), 49-57

4. Douglas D, Vyver G, (2004), Effectiveness of ELearning Course Materials for Learning Database Management. Journal of Computer Information Systems; 44(4), 41.

5. e-learning. (n.d.). Webster's New Millennium ${ }^{\mathrm{TM}}$ Dictionary of English, Preview Edition (v 0.9.6). Retrieved September 17, 2006, from Dictionary.com website: http://dictionary.reference.com/search?q=elearni ng

6. Kim E, Schniederjans M.(2004). The role of personality in web-based distance education courses. Communications of the ACM. 47(3),95100.

7. Mackay S, Stockport G. (2006). Blended Learning, Classroom and E-Learning .The Business Review, Cambridge. 5(1), 82-89

8. Mehlenbacher B, Miller C, Covington D, Larsen J. (2000) Active and interactive learning online: A comparison of Web-based and conventional writing classes. IEEE Transactions on Professional Communication..43(2), 166

9. Meng Tham C, Werner J. (2005). Designing and Evaluating E-Learning in Higher Education: A Review and Recommendations. Journal of Leadership \& Organizational Studies. 11(2), 1526

10. Munro R. (2005). Understanding the Buzz Around E-Learning: "Searching for Faster/Better/Cheaper Learning - Effectiveness of E-Learning Techniques". ASQ World Conference on Quality and Improvement Proceedings. Milwaukee: 59, 131-144.

11. Neumann P. Risks of e-education Association for Computing Machinery. Communications of the ACM. New York: (1998). 41 (10), 136

12. Nunamaker J , Zhang D, Zhao J, Zhou L. (2004). Can E-Learning Replace Classroom Learning? Association for Computing Machinery. Communications of the ACM. 47(5), 75

13. Shabha G. ( 2004). An Assessment of the Effectiveness of E-Learning on University Space Planning and Design. Facilities. 22(3/4), 79

14. Tham C, Werner J (2005) Designing and Evaluating E- learning in Higher Education. Journal of Leadership and Organizational Studies; 11(2),15-25

15. Leedy P, Ormrod J, (2005). Practical research, planning and designing 8th edition. 